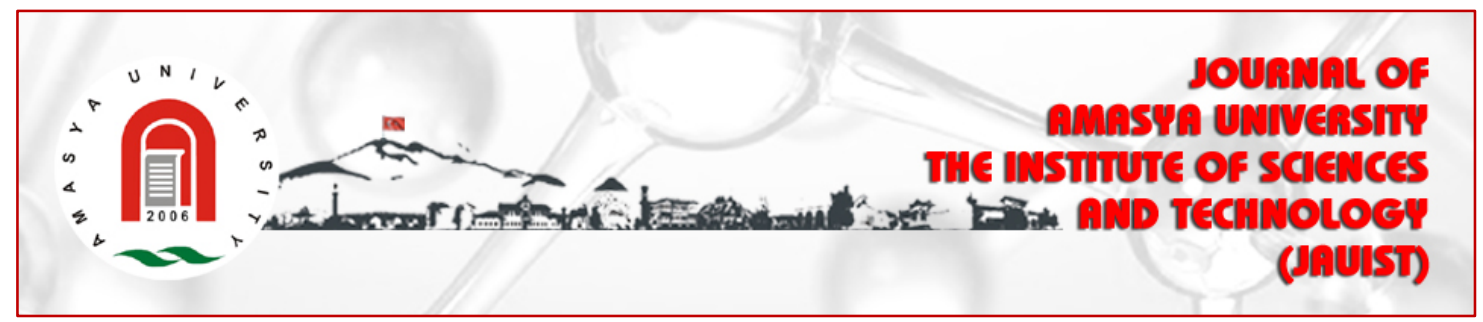

\title{
WATER TREATMENT BY ELECTROCOAGULATION
}

\begin{abstract}
AbdAl-Rhman Magdy Abdullah Youssef
Higher Technological Institute, Department of Chemical Engineering, 10 ${ }^{\text {th }}$ of Ramadan City, Egypt

ORCID: 0000-0003-2536-5201
\end{abstract}

Research Type: Review article

Received: 26.01.2021,Accepted: 08.12.2021

Corresponding author: Abdalrhman_magdy@outlook.com

https://doi.org/10.54559/jauist.868471

\begin{abstract}
Electrochemistry is the science that study, the effect of the electricity on the phase of matter by producing chemical reactions, which causes this effect. Several applications and technologies such as; batteries, fuel cells, and industries, such as aluminum industry depend on theories of electrochemistry science. Integration of electrochemistry with other chemistry science such as; environmental chemistry, contributes highly in serving environment to be clean, and safe. One of electrochemistry applications in wastewater treatment is the electrocoagulation; which considered as; one of the best water treatment methods. This technology depends on electrolysis of aluminum or steel anode, to produce ions, can be reacted with water ions, and producing new complex polymeric compounds that will flocculate the suspended particles, and deposit it in the bottom of electrocoagulation tank. Using this technology, takes avital role in cancelling the need of coagulation chemicals, and thickeners, beside that the level of electrical current that used is low. But some limits still exist; such as; the regular need to replace the anodic electrode, because it dissolves in water, electricity may be expensive in some places.
\end{abstract}

Key Words: Water, Water Treatment, Electrochemistry, Electrocoagulation 


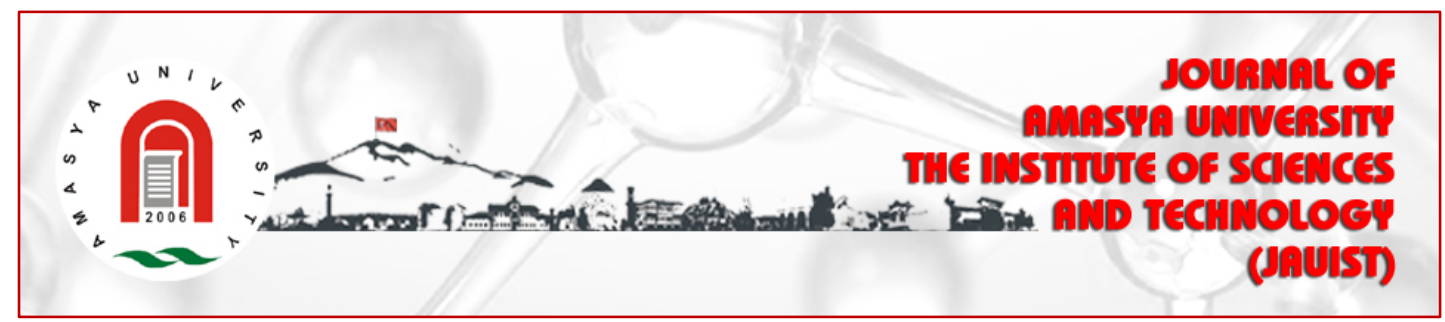

\section{Özet}

Elektrokimya, elektriğin maddenin fazları üzerindeki etkisini, bu etkiye neden olan kimyasal reaksiyonlar üreterek inceleyen bilim dalıdır. Çeşitli uygulamalar ve teknolojiler; piller, yakıt hücreleri ve alüminyum endüstrisi gibi endüstriler elektrokimya biliminin teorilerine bağlıdır. Elektrokimyanın diğer kimya bilimleri ile entegrasyonu; çevre kimyası, çevrenin temiz ve güvenli olmasına büyük katkı sağlar. Atıksu arıtımında elektrokimya uygulamalarından biri elektrokoagülasyondur; olarak kabul edilen; en iyi su arıtma yöntemlerinden biridir. Bu teknoloji, iyon üretmek için alüminyum veya çelik anotun elektrolizine bağlıdır, su iyonları ile reaksiyona girebilir ve asılı parçacıkları topaklaştıracak ve elektrokoagülasyon tankının dibinde biriktirecek yeni kompleks polimerik bileşikler üretebilir. $\mathrm{Bu}$ teknolojinin kullanılması, kullanılan elektrik akımı seviyesinin düşük olmasının yanında pıhtılaşma kimyasalları ve kıvam arttırıcı ihtiyacını ortadan kaldırmada önemli rol oynar. Ancak bazı sınırlar hala mevcuttur; gibi; anodik elektrotun düzenli olarak değiştirilmesi ihtiyacı, çünkü suda çözündüğü için elektrik bazı yerlerde pahalı olabilir.

Anahtar Kelimeler: Su, Su Arıtma, Elektrokimya, Elektrokoagülasyon 


\section{Introduction}

Since 1800, a new branch that study the effect of electricity on the chemical reactions, this study, which provides the bases of the electrochemistry science, and takes avital role to bring new applications and technologies, have their contribution in the development of several industries, and providing easier solution to the industrial problems. Electrochemistry science integrates with other sciences, such as; the environmental sciences, which provide new technologies in several fields such as; water treatment, pollution identifying and detection, and energy saving. In this research on of electrochemical technologies in wastewater treatment, that is the electrocoagulation technology will be discussed, its scientific base, advantages, disadvantages, and its mechanism.

\section{Electrochemistry}

The concept of electrochemistry referred to concepts of electricity and chemistry, which defined as the branch of chemistry that is related to the internal reactions of electricity and chemistry or in another definition it describes the effect of using electrical devices to make a change in the state of matter on the atomic scale by electron shifting. Electrochemistry term expresses about two different types of systems that are;

A) Systems that are, euilibrated thermodynamically, and as a result, there will be no change in matter state, such as; potentiometric systems, which shown in figure (1);

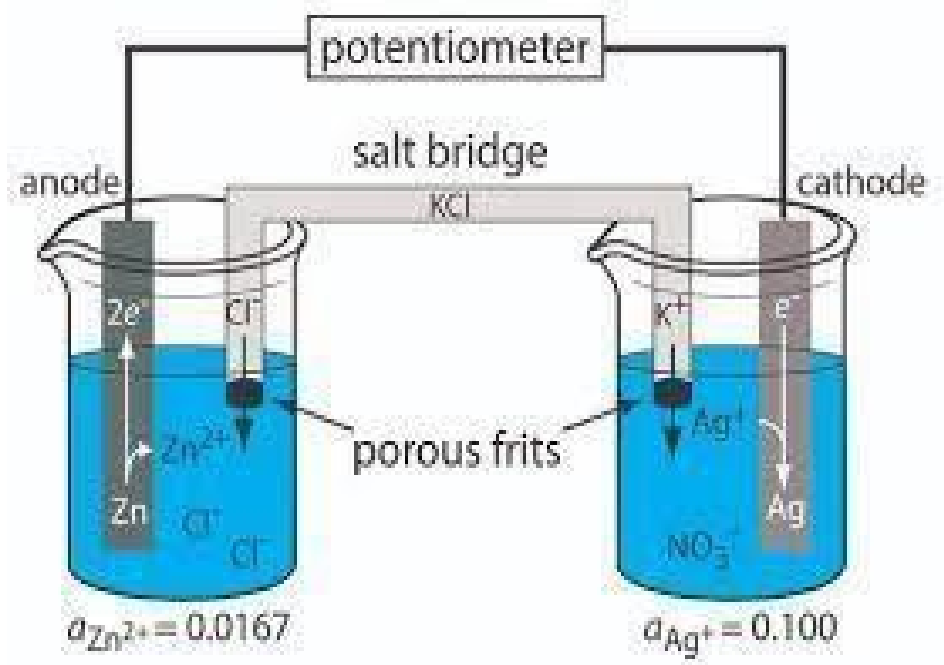

Figure 1. Example of a potentiometric electrochemical cell (Harvey, 2019). 
B) Systems that will react spontaneously, which means that there will be a change in the state of matter due to exchange of electrical energy, such as; corrosion.

The history of electrochemistry dating back to 18th century when the galvanic cell is discovered, and through two centuries the basis of electrochemistry science is

formed. Now electrochemistry application be in varied fields, which shown in figure (2), such as;

- Electroplating; this application is used to cover a matter with a coat from other material for purposes of giving a shiny view, or protection from corrosion.

- $\quad$ Chloralkali; the redox reactions is used in manufacturing of sodium hydroxide.

- Batteries; is used to store electrical energy chemically, which allowing to reuse this stored energy.

- Fuel cells; it can be distinguished from the batteries by its continuous work, as it is used to generate electricity not to store it, by using a fuel such as; hydrogen and an oxidant such as; oxygen.

- Wastewater treatment (electrocoagulation); wastewater treated electrochemically depending on electrical nature of ions as cations, and anions.

- Aluminum production; depends on redox reactions to extract Aluminum from its source bauxite source.

- Electrochemical sensors; which is used to detect oxygen and other toxic gases (Analytical Technology, 2019)

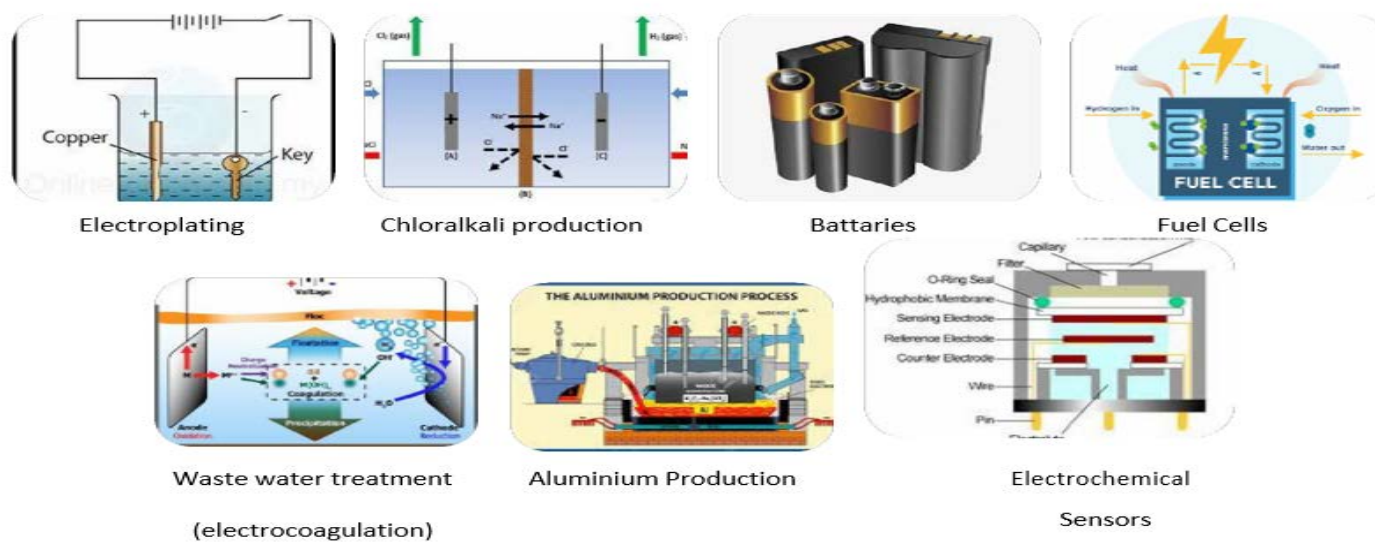

Figure 2. Different applications of electrochemistry 


\section{Environmental Electrochemistry}

Electrochemistry meets with other chemistry branches for purpose of science integrating, so number of chemistry branches are founded such as; inorganic, environmental, and physical...etc.

Figure (3) shows the different branches of electrochemistry.

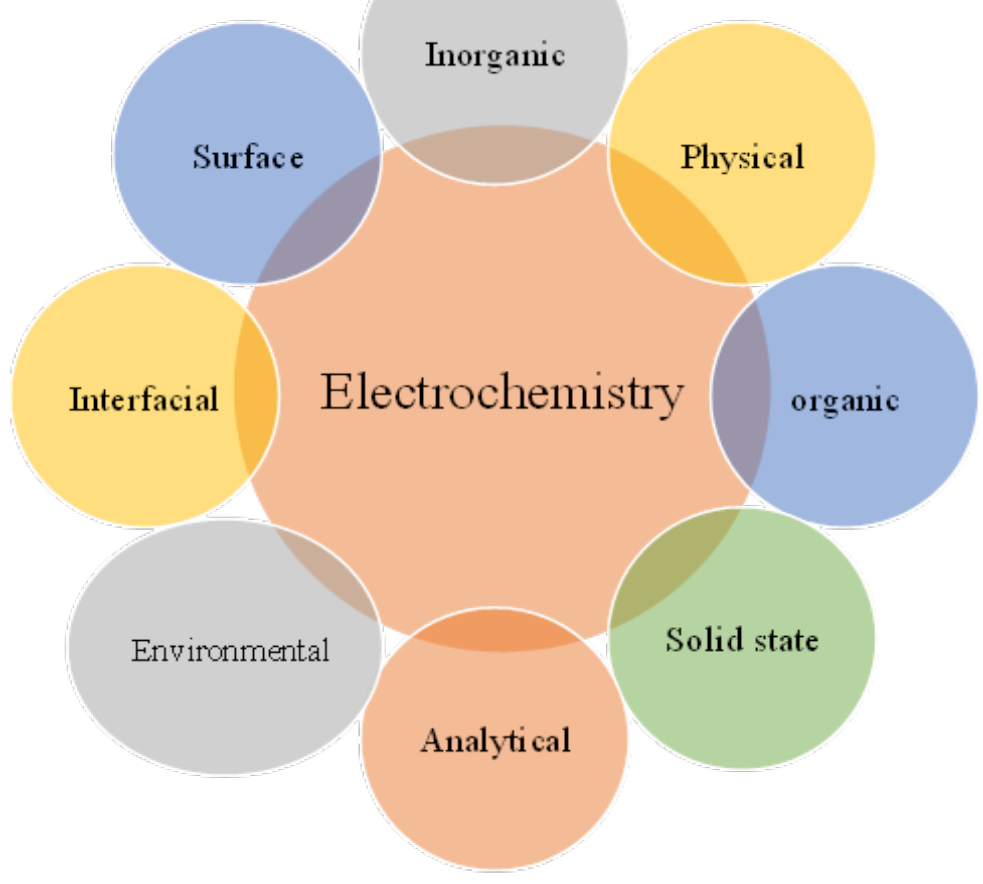

Figure 3. Different branches of electrochemistry

Environmental electrochemistry; is that branch of electrochemistry that related to environment chemistry and problems, environmental electrochemistry has varied application to keep the environment safe. Electrochemical processes safe and lowcost processes, as it occurs in low temperature due to the used electrolyte, which provides aqueous media where electrodes are immersed. Also, electrochemical desired and undesired products don't leave, which give the ability for; Pollution detection, treatment of wastewater, recycling of metals, and founding new sources of energy that more effective from the usual used sources. 


\subsection{Pollution Identifying using electrochemical sensors}

One of environmental electrochemistry using is identifying pollution in case of; gas, liquid, and solid by sensors prepared for this purpose. Pollution identifying is done by electrochemical sensors, that represent a class of chemical sensors, electrochemical sensors formed by collection both of receptor, and electrochemical transducer. The electrochemical transducer used for transforming, the internal electrochemical reaction to an electrical signal, abled to be measured (Zlatev, 2014). Electrochemical sensors classified into three types;

- Potentiometric sensors;

It's an important tool used for two purposes. The first purpose is for measuring redox potential, and the second as an analytical tool for measuring a variety of ionic, and ionizable spices, and as shown in figure (4); the potentiometric sensor composed of indicator electrode, which has a potential measured against reference electrode potential. (Ligia Maria Moretto, 2014)

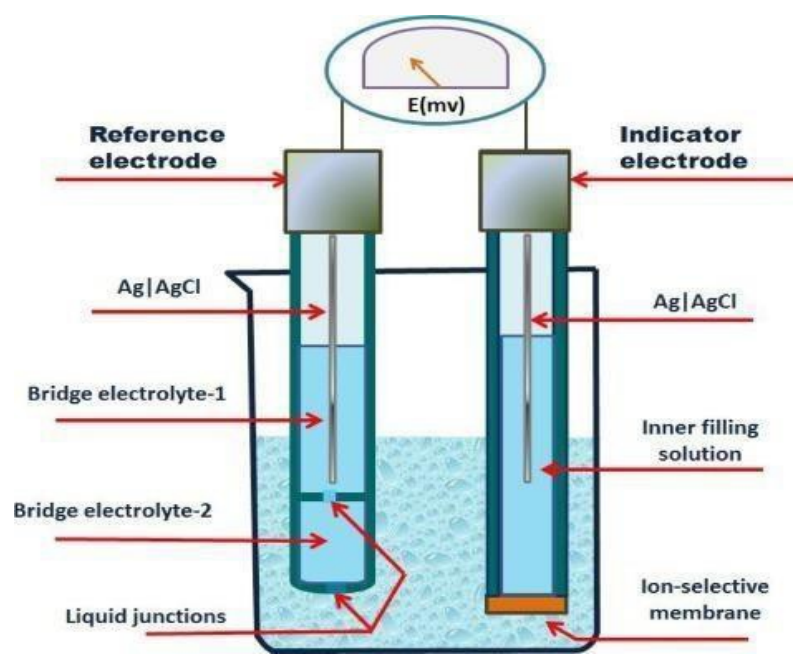

Figure 4. Real time potentiometric sensor, (Ahmed Ma'mun, 2018)

- Voltametric sensors;

In which the current measured to control potential of indicator electrode, and response of electric current, which measured directly, or in alternating current mode (Zlatev, 2014). The current that measured is proportional to the concentration of present electroactive species (Ligia Maria Moretto, 2014). Figure (5) shows a voltametric sensor. 
A

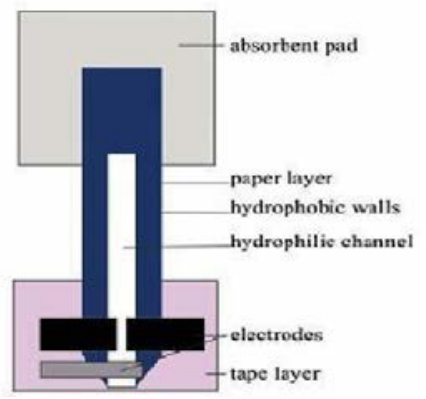

B

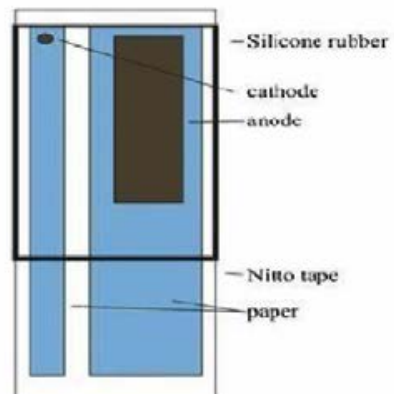

C

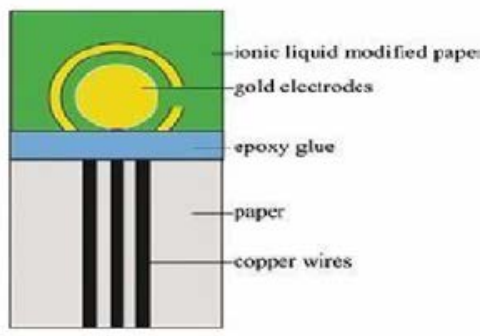

Figure 5. Examples of voltametric sensors: (a) stripping voltammetry measurement of $\mathrm{Pb}(\mathrm{II})$, (b) Clark-type oxygen electrode, (c) oxygen sensor based on nano porous gold. (Kubota, 2013)

- Conductometric Sensors;

They are usually bipolar devices, and depending on current conductance. Also, they aren't similar in their configuration with different equivalent electrical circuit diagram dependence on selective layer as shown in figure (6. a, and b). In figure (6.a) the measurement will depend on using of DC current due to resistance of chemi-resistors, and in figure (6.b) the measurement will depend on AC current which makes it as electrochemical cell. (Janata, 2009).
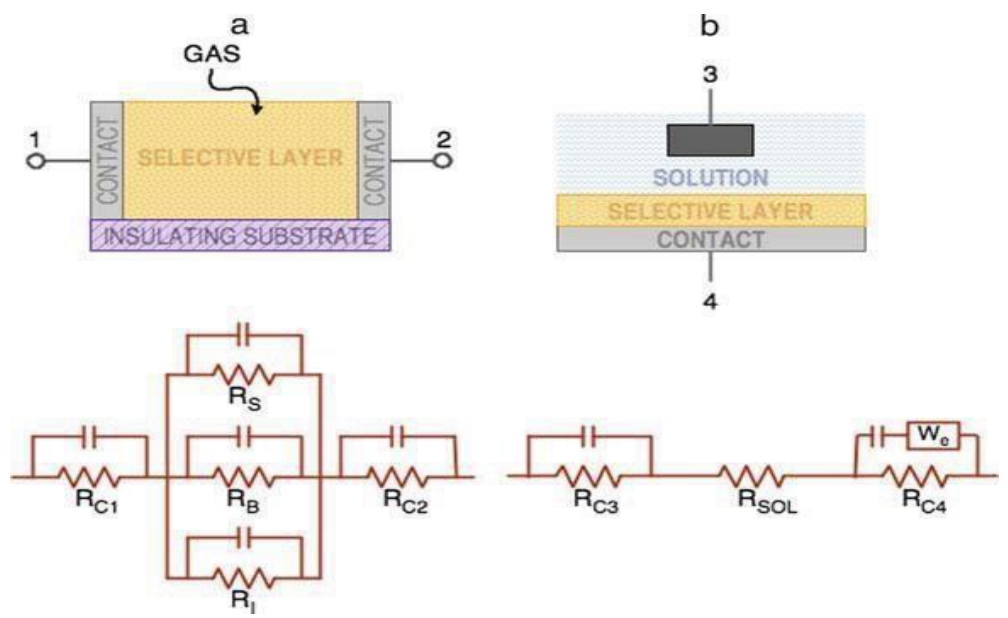

Figure 6. General chemiresistors and their equivalent circuits: (a) lateral configuration in which any of the five resistances can be modulated by chemical interaction; (b) impedimetric chemiresistor in which capacitance CB is chemically modulated, (Janata, 2009) 


\subsection{Pollution treatment}

Electrochemical methods are suitable in the purpose of treatment of various pollutants dependence on electrokinetic, in which the electrical current passed through electrodes that are buried underground, which cause moving of charged and uncharged species. This method is suitable for treating of organic, inorganic, and radioactive pollutants, (Zlatev, 2014).

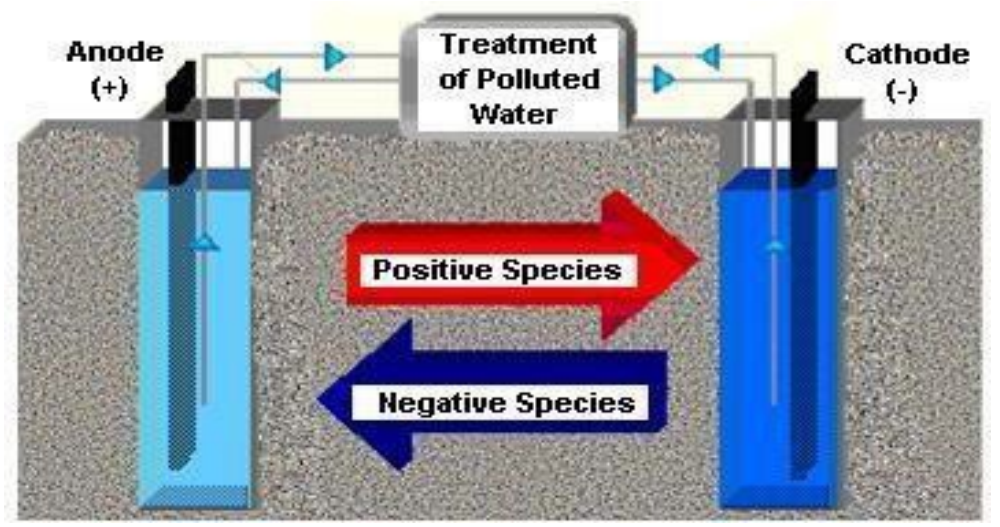

Figure 7. Electromigration of ions in an electrochemical arrangement to remove pollutant from the matrix (V. Valdovinos, 2014)

\section{Applications of Electrochemistry in Waste Water Treatment}

Treatment of water is electrochemically is classified from the physical methods of water and waste water treatment. Also, it is characterized by its nature as a multi stage. It combines between chemical and physical phenomena, which is observed in electrolyzers; that considered a type of reactors that its working principle depend on electrochemistry science. Dependence on both of chemical and physical properties of targeted water, electrochemical water treatment methods is classified into three classes, which shown in figure (8), which are; Conversion, separation, combined methods (Shestakova, 2017) . 


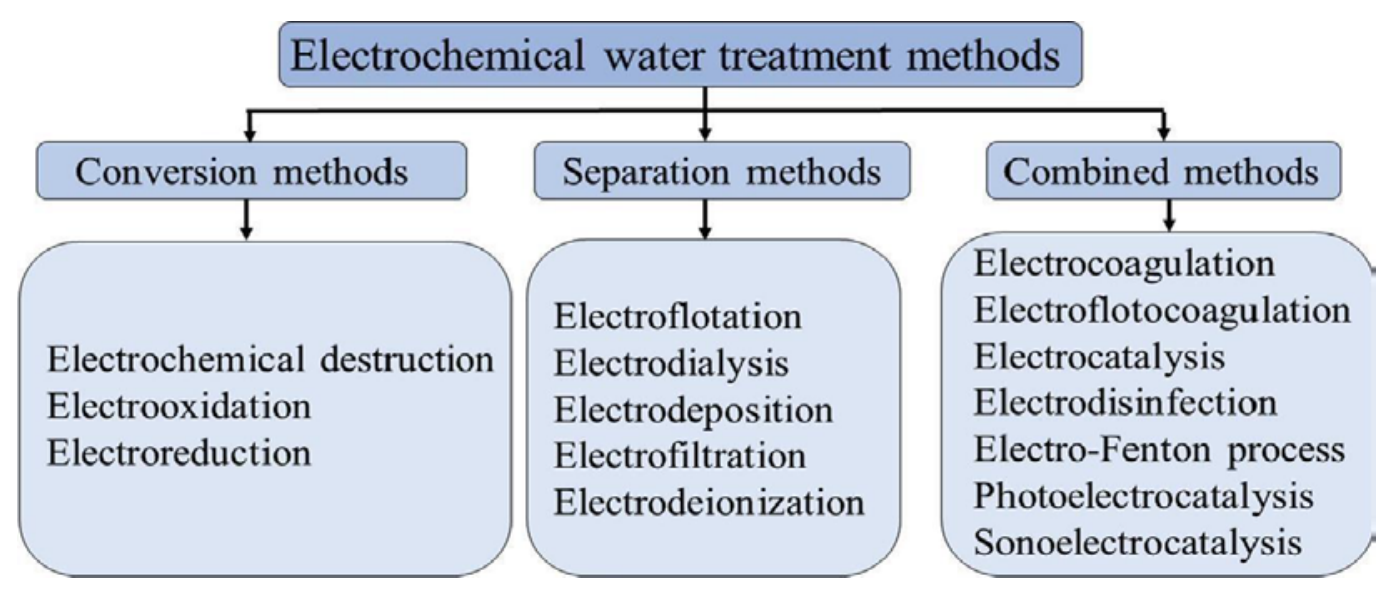

Figure 8. Classification of electrochemical methods by the mechanism of treatment (Shestakova, 2017)

\subsection{Conversion Methods}

It used for change of the physical and chemical phase of pollutants that exist in waste water treatment. Phase transformation of impurities done in number of series of successive stages. three techniques in waste water treatment represent the conversion method, that are; electrochemical destruction, electrooxidation, and electroreduction (Shestakova, 2017).

\subsection{Separation Methods}

It used in reducing of pollutants concentration in solution volume without phase or chemical or physical properties. Impurities separation depend on electrogenerated in electro flotation or by electric field power, which make particles transport in water. Five techniques in waste water treatment represent the separation method, that are; electro flotation, electrodialysis, electrodeposition, electro filtration, and electro deionization (Shestakova, 2017).

\subsection{Combined Methods}

It's not considered as a unique methods or techniques due to its nature as hybrid techniques, formulated from both of conversion and separation techniques, which give more effective results for water treatment process. This hybridization between conversion, and separation methods gives the hoped results when it generates new hybrid techniques that are; electrocoagulation, electro flotation, electro disinfection, electro-Fenton process, photo electrolysis, and son electrolysis. As an example; electrocoagulation depends on electrolysis process using anodes from steel or aluminum in electrolysis process (Shestakova, 2017). 


\section{Scientific Base of Electrocoagulation}

Generally, concept of coagulation means that; the aggregates stability lost in the system that it disperses in it, which led finally to separate those aggregates. As mentioned previously that, electrocoagulation technique belonged to the combined method, which mean that it grounded on a hybrid of two scientific ideas. The first idea concerned about the conversion technique which depend simply on redox reaction (Erick Butler, 2011), which cause phase change to the impurities. Under effect of direct current; cathode oxidize, and lose electrons, and in other side aluminum or steel anode in water and forming complex hydroxide compounds, which work as coagulants, that its role concluded in initiating of fusion of particles, (Shestakova, 2017), formulating flakes, and deposited in the bottom of the treatment tanks as shown in figure (9). In deposition stage the role of conversion method end, and separation techniques start to take its role which presented in removal of all those deposited flakes, and then one of separation techniques can be used for the purpose of removal of deposited flakes.

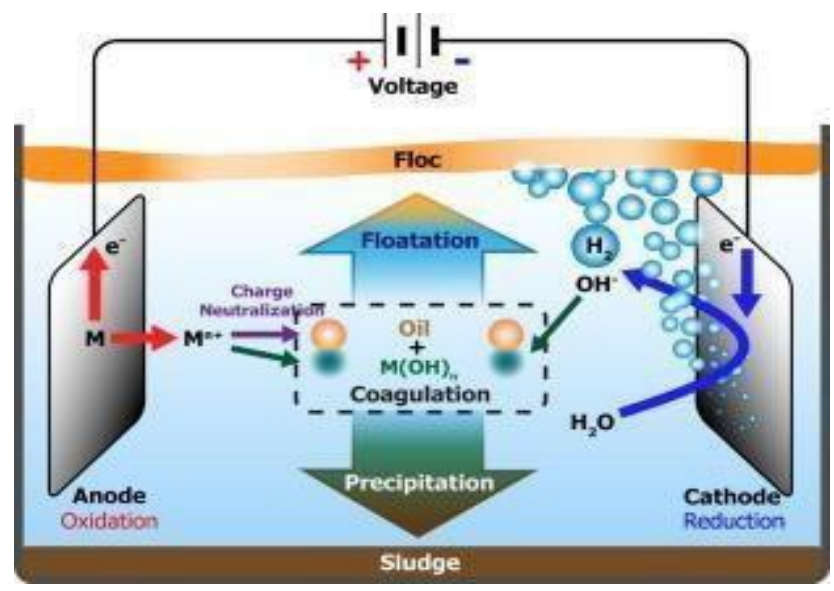

Figure 9. Electrocoagulation Mechanism, (ChunjiangAn, 2017)

\section{Benefits of Electrocoagulation}

Electrocoagulation is a very success technology, in the field of waste water treatment, and due that there's a number of advantages that distinguish using of electrocoagulation technology for water treatment, these advantages are;

- In using of this technology; the chemicals that used in ordinary to play the role of coagulant, aren't needed. Those chemicals might be toxic or left odor on water, so using electrocoagulation technology protect from this dangerous. 
- Beside non using of chemical coagulants, thickeners are not used which play a vital role in cost decreasing.

- Using of electrocoagulation decrease percentage of suspended particles in water as much as 95-99 percentage.

- Electrocoagulation technology depend on electrolysis, which give this technology the ability of recycling metals in pure form unlike the other techniques.

- Using electrolysis in electrocoagulation, open the discussion about the level of the electrical current that used for treatment of water, is the level of the electrical current high or low?

In fact, the level of the electrical current, that used in electrocoagulation process is a low level which distinguish this process (ADVANTAGES AND DISADVANTAGES OF ELECTROCOAGULATION WATER TREATMENT, 2020).

- Waste water that combined with concentrated oil (up to $10 \mathrm{~g} / \mathrm{l}$ ), can be treated using electrocoagulation technology, in case of using aluminum anode. In case of existence of nonferrous solids such as; $\mathrm{Zn}, \mathrm{Cu}, \mathrm{Ni}, \mathrm{Cd}$, and $\mathrm{Cr}(\mathrm{IV})$ in waste water can be removed using electrocoagulation, in case of using steel anode (Shestakova, 2017).

\section{Disadvantageous of Electrocoagulation}

Although all privileges, that come from using electrocoagulation technology, this technology hold inside its system sum disadvantages related to the working of the system, that are;

- Anode; that dissolved in water to formulate hydroxides that play the rule of the coagulant, which means that, this electrode needs to be changed regularly, depending on the amount of waste water that targeted to treated, and volume of the anodic electrode.

- Although, electrolysis process, that considered the base electrocoagulation technology, requires low level of electrical current, but in some places electricity cost is expensive (Beagles, 2004).

- Also, during electrolysis a film formulated from the deposited compounds, which reduce efficiency of the electrolysis process, which means that cathodic electrode needs to be cleaned (pagina's, 2010).

\section{Electrocoagulation Processes description}

As shown in figure (10), interactions of electrocoagulation unit start when a DC current pass to anode which allow to anode to be oxidized, and produce aluminum, or iron ions, when using steel anode, as shown in the next equations; 
In case if $\mathrm{Al}$ anode; $\mathrm{Al}(\mathrm{s}) \rightarrow \mathrm{Al} 3++3 \mathrm{e}-$

In case of steel anode; $\mathrm{Fe}(\mathrm{s}) \rightarrow \mathrm{Fe} 2++2$ e-

The second electrode, and water divided to Hydrogen $(\mathrm{H}+)$, and hydroxide $\left(\mathrm{OH}_{-}\right)$ions, the metallic ions dissolved in water, which formulate poly hydroxides compounds which collect and aggregate the suspended particles in waste water, and then deposited in bottom of reactor to be separated (Bharath M, 2018).

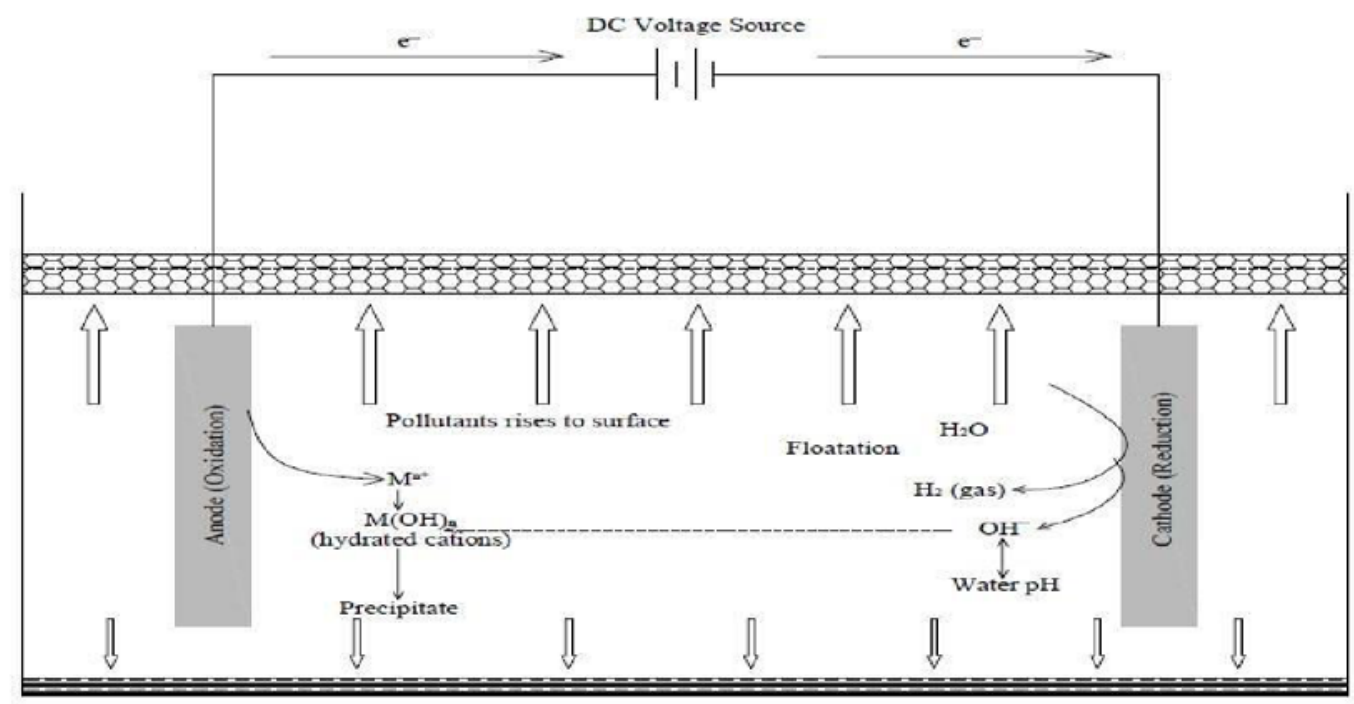

Figure 10. Diagram of a bench scale Electrochemical reactor, (Bharath.M, 2018)

\section{Conclusion}

Electrochemistry is the science that related to hanging of natter state or phase, using the electrical current. Electrochemistry integrates with other chemistry branches, for developing new applications, can be useful industrially, and one of this integration results is environmental electrochemistry science, which provide useful solution for detection of pollution and treatment it, and also, other several solutions for energy saving, and water treatment. Electrochemical technologies that used in water treatment are varied, and one of them is electrocoagulation that, by using it, there will be no need to coagulation chemicals, and also, the suspended metals can be recycled. Although these advantages, using this technology create the need to change anode regularly.

\section{Dedication}

This work is dedicated to my professors; 
Mr. Major Jeneral Prof. Dr. Eng. Maher Gamal Amin Soliman

Mr. Major Jeneral Prof. Dr. Eng. Mostafa Hamdi Azab

\section{Acknowledgements}

I would gratefully determine my acknowledgements o my dear Prof. Randa Mohamed Othman, for her advice.

\section{Conflicts of interest}

The authors declare that there are no potential conflicts of interest relevant to this article.

\section{References}

(n.d.). Retrieved May 12, 2020, from kindpng:

https://www.kindpng.com/imgv/ixwRomm clipart-at-clker-many- batteriesclipart-hd/

(n.d.). Retrieved May 12, 2020, from kissclipart:

https://www.kissclipart.com/examples-ofelectroplating-in-daily-life-cliparte- j94juk/

(2019). Retrieved May 14, 2020, from Analytical Technology: https://www.analyticaltechnology.com/analyticaltechnology/gaswatermonitor s/blog.aspx?ID=1327\&Title=How\%20Do\%20Electrochemical \%20Sensors\%20Work

Advantages and disadvantages of electrocoagulation water treatment.(2020, April 2). Retrieved May 21, 2020, from chemtech international: https://chemtechus.com/advantages-anddisadvantages-ofelectrocoagulation- water-treatment/

Ahmed Ma'mun, M. K.-R.-K. (2018). Real-time potentiometric sensor; an innovative tool for monitoring hydrolysis of chemo/bio-degradable drugs in pharmaceutical sciences. Journal of Pharmaceutical and Biomedical Analysis, 154, 166-73. doi:https://doi.org/10.1016/j.jpba.2018. 02.007

Beagles, A. (2004). Electrocoagulation (EC) - Science and Applications. Retrieved May 21, 2020, from Green Pages: https://ecoweb.com/edi/050526.html

Bharath M, K. B. (2018). A Review of Electrocoagulation Process for Wastewater Treatment. International Journal of ChemTech Research, 11, 289-302. 
Christine Lefrou, P. F.-C. (2012). Electrochemistry The Basics, With Examples. Verlag Berlin Heidelberg: Springer.

ChunjiangAn, G. Y. (2017). Emerging usage of electrocoagulation technology for oil removal from wastewater: A review. (J. Gan, Ed.) Science of The Total Environment, 579, 537556.

Erick Butler, Y.-T. H.-L. (2011). Electrocoagulation in Wastewater Treatment. water, 495525. doi:10.3390/w3020495

Eurotransis. (2019, Jan https://eurotransis.com/en/what-corrosion-is-and-how- toavoid-it/). What corrosion is and how to avoid it? Retrieved May 12, 2020, from eurotransis.

Fuel Cell \& Hydrogen Energy Basics. (2019, Aug 1). Retrieved May 12, 2020, from FCHEA: http://www.fchea.org/h2-day-2019-events-activities/2019/8/1/fuel-cellamphydrogenenergy-basics

Harvey, D. (2019). Potentiometric Methods. Retrieved May 12, 2020, from libretexts: https://chem.libretexts.org/Courses/Northeastern_University/11\%3A_Electro Chemical_M ethods/11.2\%3A_Potentiometric_Methods

Janata, J. (2009). Principles of Chemical Sensors (second ed.). Dordrecht, Heidelberg, London, and New York: Springer.

Kubota, E. W. (2013). Sensing approaches on paper-based devices: a review. Analytical and Bioanalytical Chemistry. doi:10.1007/s00216-013-6911-4

Ligia Maria Moretto, K. K. (2014). Environmental Analysis by Electrochemical Sensors and Biosensors Fundamentals (Vol. 1). New York: Nanostructure Science and Technology ,Springer.

Pagina's, G. (2010). Elektrocoagulation. Retrieved May 21, 2020, from emis: https://emis.vito.be/en/bat/tools-overview/sheets/elektrocoagulation.

Phonnipha Boriboonsuksri, A. N.-K. (2017). A Prototype of Industrial Waste Water Treatment Using Electrocoagulation. MATEC Web of Conferences. doi:10.1051/matecconf/2017950

Shestakova, M. S. (2017). Electrochemical Water Treatment Methods Fundamentals, Methods and Full Scale Applications. Oxford: ButterworthHeinemann. 
AbdAl-Rhman Magdy Abdullah Youssef. (2021). Water Treatment by Electrocoagulation. Journal of Amasya University the Institute of Sciences and Technology, 2(2), 1-15

V. Valdovinos, F. M.-G. (2014). Treatment Methods for Radioactive Wastes and Its Electrochemical Applications. In M.C.Soriano, Environmental Risk Assessment of Soil Contamination. Intech open. doi:10.5772/57445.

Zlatev, M. S. (2014). Encyclopedia of Applied Electrochemistry. (G. Kreysa, K.-i. Ota, \& R. F. Savinell, Eds.) New York, USA: Springer. 